\title{
KAJIAN POTENSI SUMBERDAYA PERIKANAN DI PROVINSI KEPULAUAN BANGKA BELITUNG
}

Study of Fisheries Resources Potentials in the Province of Kepulauan Bangka Belitung

Oleh:

Mario Limbong

\author{
Jurusan Pemanfaatan Sumberdaya Perikanan, Fakultas Perikanan dan Ilmu Kelautan, \\ Universitas Satya Negara Indonesia \\ Jl. Arteri Pondok Indah No.11 Jakarta Selatan 12240 \\ Email: limbong_mu@yahoo.com
}

\begin{abstract}
ABSTRAK
Pemanfaatan sumberdaya ikan di Indonesia saat ini sudah mengarah kepada upaya pengendalian dan cenderung menuju tahapan yang overfishing. Apabila kondisi ini berjalan terus menerus dikhawatirkan akan terjadinya penurunan stok sumberdaya ikan. Adanya Keputusan Menteri Kelautan dan Perikanan Republik Indonesia No.50/Kepmen-KP/2017 menjadi dasar yang kuat untuk pengendalian dan pengelolaan perikanan di Indonesia, khususnya di Provinsi Kepulauan Bangka Belitung. Penelitian ini bertujuan untuk melihat kondisi eksisting perikanan tangkap dan menghitung alokasi kuota sumberdaya ikan di Provinsi Kepulauan Bangka Belitung. Berdasarkan hasil analisis, kondisi perikanan tangkap di Provinsi Kepulauan Bangka Belitung sudah mengalami kelebihan penangkapan (overfishing) yaitu melampaui JTB sekitar 106,54\%. Alokasi kuota penangkapan untuk wilayah perairan Provinsi Kepulauan Bangka Belitung setiap tahun diharapkan berada pada kisaran 175.916,71 ton sehingga tercipta usaha penangkapan ikan yang berkelanjutan. Rata-rata produksi perikanan tangkap di Provinsi Kepulauan Bangka Belitung mulai tahun 2012-2017 sekitar 187.421,42 ton yang sebagian besar didaratkan di PPN Sungailiat dan PPN Tanjung Pandan. Alokasi JTB untuk Pemerintah Daerah di WPP 711 sebesar 417.315,32 ton/tahun sedangkan untuk Pemerintah Pusat mendapat alokasi sekitar 196.383,68 ton/tahun. Arah kebijakan pengembangan usaha perikanan tangkap di Provinsi Kepulauan Bangka Belitung antara lain pengendalian kegiatan usaha penangkapan di daerah pesisir dan mengarahkan menuju laut lepas (zona ekonomi ekslusif). Oleh sebab itu, diperlukan peran pemerintah pusat untuk pengembangan program peningkatan skala usaha penangkapan melalui
\end{abstract}


penambahan armada diatas 30 GT. Selain itu, perlu dikaji juga jumlah alat tangkapan dan armada penangkapan yang optimum di Provinsi Kepulauan Bangka Belitung yang sesuai dengan alokasi kuota sumberdaya ikan yang ditetapkan oleh pemerintah pusat.

Kata kunci : Potensi perikanan, alokasi kuota sumberdaya ikan, Provinsi Kepulauan Bangka Belitung

\section{Kata kunci: potensi perikanan, alokasi kuota sumber daya ikan, Provinsi Kepulauan Bangka Belitung}

\section{PENDAHULUAN}

Indonesia merupakan sebuah negara kepulauan (archipelagic state), di mana luas lautnya kurang lebih $65.301 \mathrm{~km}^{2}$ atau 79,90\% dari luas keseluruhan 81.725,14 km². Dengan berbagai potensi sumberdaya, baik yang dapat diperbaharui muapun yang tidak dapat diperbaharui. Pemanfaatan dan perhatian terhadap sumberdaya perikanan saat ini diharapkan mampu mewujudkan cita-cita bangsa ini, yaitu terciptanya masyarakat yang adil dan makmur. Pada saat ini pemanfaatan sumber daya ikan di Indonesia sudah mengarah kepada upaya pengendalian dan cenderung menuju pada tahapan yang over fishing. Apabila kondisi ini berjalan terus menerus dalam jangka panjang dikhawatirkan akan terjadinya penurunan stok sumber daya ikan yang selanjutnya akan mengancam kelestarian sumberdaya tersebut dan lebih memiskinkan nelayan. Dalam perspektif yang demikian, maka seluruh stakeholder perikanan tangkap harus bersinergi dalam merumuskan dan menjalankan konsep-konsep penguatan pengelolaan. Dengan demikian, sumberdaya ikan akan dapat dimanfaatkan secara optimal dan bekelanjutan bagi kepentingan pembangunan perikanan di Indonesia. Cara penguatan pengelolaan yang terumuskan dan terimplementasikan dengan baik akan sangat berperan dalam mewujudkan industrialisasi perikanan tangkap yang berbasis ekonomi biru yang fokusnya pada peningkatan produktivitas dan nilai tambah. Penguatan pengelolaan tersebut sangat memerlukan hasil penelitian tentang status stok terutama data potensi dan tingkat pemanfaatan untuk mendasarinya.

Potensi ikan laut dan Jumlah Tangkapan yang Diperbolehkan (JTB) beberapa kelompok spesies ikan seperti, pelagis besar, pelagis kecil, demersal, udang, cumi-cumi, ikan hias, moluska dan tripang, benih alam komersial, ikan konsumsi perairan karang pertama kali ditetapkan melalui Keputusan Menteri Pertanian No. 995/Kpts/IK 210/9/99. Pada tahun 2011 dilakukan 
kajian ulang pertama kali setelah wilayah pengelolaan perikanan (WPP) berubah menjadi 11 WPP dan metoda yang dipergunakan sudah menggabungkan metode holistik dan analitik. Hasil kajian ini telah dibuat menjadi dasar kebijakan pemanfaatan sumber daya ikan di Indonesia dan ditetapkan dalam Keputusan Menteri Kelautan dan Perikanan (KepMen KP. No. 45 Tahun 2011). Pada tahun 2018, adanya Keputusan Menteri Kelautan dan Perikanan Republik Indonesia No.50/Kepmen-KP/2017 tentang Estimasi Potensi, Jumlah Tangkapan Yang Diperbolehkan (JTB) dan Tingkat Pemanfaatan Sumberdaya Ikan di Wilayah Pengelolaan Perikanan Negara Republik Indonesia menjadi dasar untuk mengelolah potensi perikanan. Total potensi ikan yang ada di perairan laut Indonesia sebanyak 12.541.438 ton, dengan JTB sebanyak 10.033.150 ton.

Provinsi Kepulauan Bangka Belitung memiliki luas wilayah perairan laut $65.301 \mathrm{~km}^{2}$ (80\%) dan panjang garis pantai $1.200 \mathrm{~km}$. Dengan kondisi demikian, provinsi ini tentunya menyimpan potensi perikanan yang cukup beragam dan jumlahnya besar. Secara geografis, Provinsi Kepulauan Bangka Belitung merupakan salah satu provinsi yang berkepentingan dalam pengelolaan perikanan tangkap di WPP 711. Pemanfaatan potensi perikanan diharapkan mempercepat pembangunan terutama ekonomi perikanan yang berkelanjutan namun harus memperhatikan kelestarian sumberdaya ikan dan lingkungan. Oleh karena itu, diperlukan kajian Potensi Perikanan di Perairan Provinsi Kepulauan Bangka Belitung. Kajian potensi perikanan ini diharapkan memberikan gambaran mengenai kondisi kegiatan perikanan tangkap di wilayah Perairan Provinsi Kepulauan Bangka Belitung sehingga penangkapan ikan tetap memperhatikan kelestarian sumberdaya ikan dan ekosistem. Diharapkan dengan adanya besaran JTB untuk perairan Provinsi Kepulauan Bangka Belitung yang sesuai dengan kajian, maka pembangunan perikanan dapat diarahkan kepada sistem perikanan yang berkelanjutan.

\section{METODOLOGI}

Penelitian Kajian Potensi Sumberdaya Perikanan di Provinsi Kepulauan Bangka Belitung dimulai bulan Oktober 2018 sampai dengan bulan Desember 2018. Adapun yang menjadi lokasi pengambilan data, diantaranya PPI Muntok di Kabupaten Bangka Barat, PPN Sungailiat di Kabupaten Bangka, PPI Kurau di Kabupaten Bangka Tengah, PPI Gantung di Kabupaten Belitung Timur dan PPN Tanjung Pandan di Kabupaten Belitung. Jenis data yang digunakan dalam penelitian ini adalah data kualitatif dan kuantitatif. Sumber data yang dijadikan sebagai referensi dalam kajian ini adalah menggunakan data sekunder dan data primer. Jenis dan 
kebutuhan data dapat dilihat pada Tabel 1. Teknik pengumpulan data yang digunakan adalah purposive sampling dan incidental sampling. Alat dan bahan yang digunakan dalam penelitian ini meliputi software statistik dan Microsoft Excel untuk mengolah data statistik sedangkan data time series Statistik Perikanan Tangkap sebagai bahan data yang diolah.

Tabel 1 Jenis dan kebutuhan data

\begin{tabular}{llll}
\hline No & \multicolumn{1}{c}{ Jenis Data } & \multicolumn{1}{c}{ Sumber } \\
\hline Data Primer & & \\
\hline 1 & Perikanan Tangkap & Wawancara mendalam \\
dan kuesioner & Profil keragaan usaha penangkapan \\
& SDM dan & Kuesioner dan & Kondisi sosial -konomi, sosbud, \\
2 & Kelembagaan & wawancara & kelembagaan masyarakat dan usaha \\
& Mayarakat & Wawancara mendalam & Rantai pemasaran, pelaku usaha, \\
& Pemasaran & dan kuesioner & omset, harga \\
& & Ground check dengan & PP, TPI, Pabrik Es, Cold Srorage, \\
& Infrastruktur & GPS dan pengambilan & SPBN, Air Bersih, Listrik, \\
& Penunjang & gambar & Telekomunikasi,
\end{tabular}

Data Sekunder

KKP (Komnaskajiskan), Armada, Alat Tangkap, RTP,

1 Perikanan Tangkap DKP Provinsi dan DKP Teknologi, Skala usaha, Produksi

Kabupaten/Kota Hasil Tangkapan

SDM dan

2 Kelembagaan BPS

Mayarakat

Pendapatan, Pekerjaan, lembaga

sosial dan usaha

3 Pemasaran

DKP Babel, Diperindag Rantai pemasaran, pelaku usaha, Babel, Diskop UKM omset, harga

Infrastruktur

PP, TPI, Pabrik Es, Cold Srorage, 4 Penunjang

Dinas PU, Dishub, DKP SPBN, Air Bersih, Listrik,

Telekomunikasi,

Wilayah Provinsi Kepulauan Bangka Belitung berada di WPP 711 yang mana wilayah tersebut merupakan wilayah penangkapan ikan oleh nelayan-nelayan yang berada di 7 provinsi. Untuk 
mengetahui potensi pemanfaatan sumber daya ikan perikanan tangkap Provinsi Kepulauan Bangka Belitung dilakukan analisis dengan pendekatan pembagian/alokasi kuota (AK) per provinsi dengan rumus sebagai berikut (Indrajaya, 2014):

$$
A K_{i}=T_{-} \text {rata } \quad+
$$

Dimana:

$T_{-}$rata $_{i}$ : Rata-rata hasil tangkapan (dalam ton) yang dilaporkan dalam 5 (lima) tahun terakhir.

$W_{1} \quad: \quad$ Jumlah nelayan

$W_{2} \quad$ : Ketergantungan ekonomi terhadap SDI

$W_{3} \quad$ : Luas perairan

$W_{4} \quad$ : Skala usaha penangkapan ikan

$W_{5} \quad$ : Kesiapan industrialisasi

$C F_{1} \quad: \quad$ Aktivitas konservasi

$\mathrm{CF}_{2} \quad$ : Tingkat kepatuhan

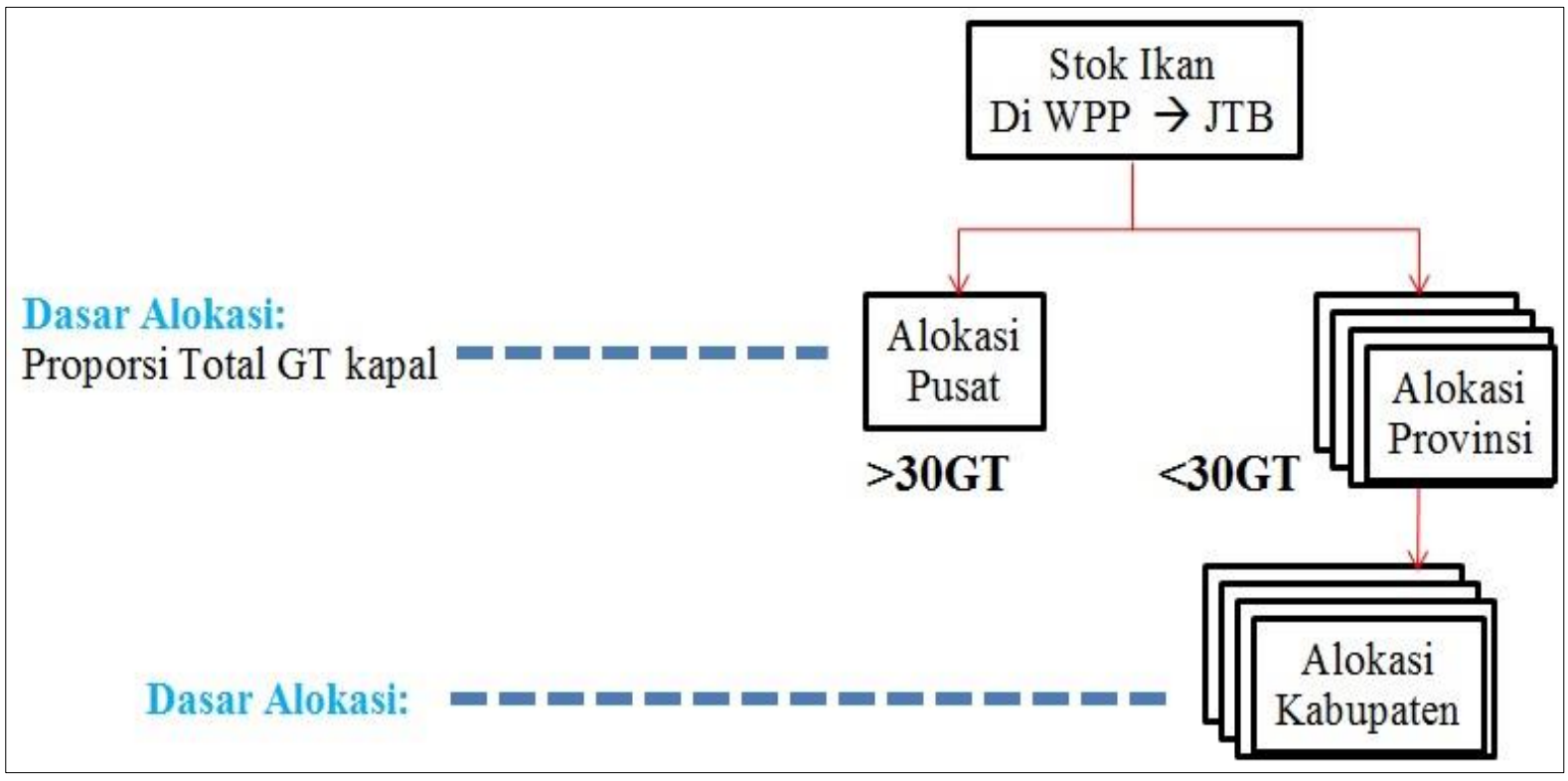

Gambar 1 Alokasi JTB untuk provinsi dan kabupaten

Untuk menjamin agar supaya total alokasi untuk semua daerah/pengusaha penangkapan tidak melampaui JTB, maka alokasi kuota (AK) untuk setiap Pengusaha Penangkapan perlu disesuaikan/dikoreksi sebagai berikut: 
Dimana $\mathrm{JTB}_{97,5}$ adalah JTB setelah dikurangi 2,5\% untuk cadangan stok atau bagi Daerah/Pengusaha Penangkapan yang akan masuk berikutnya. Tahapan penentuan alokasi kuota sumberdaya perikanan dapat dilihat pada Gambar 1.

\section{HASIL DAN PEMBAHASAN}

Produksi perikanan tangkap laut di Provinsi Kepulauan Bangka Belitung tahun 2017 tercatat sebesar 217.959,17 ton atau naik sebesar 15,58 persen jika dibandingkan dengan produksi tahun 2016 yaitu sebesar 188.572,60 ton. Produksi perikanan laut terbesar yaitu Kabupaten Belitung, Kabupaten Belitung Timur dan Kabupaten Bangka Selatan. Sedangkan produksi perikanan laut terendah berada di wilayah Kabupaten Bangka Barat dan Kota Pangkal Pinang. Berdasarkan data tersebut, terlihat bahwa potensi perikanan tangkap, khususnya produksi perikanan laut terkonsentrasi di Pulau Belitung jika dibandingkan dengan perikanan di Pulau Bangka secara umum. Oleh sebab itu, pengembangan investasi perikanan tangkap lebih baik dilakukan di Pulau Belitung karena memiliki cakupan perairan yang lebih luas. Mayu et.al, (2018), sumberdaya ikan pelagis kecil selama tahun 2012-2016 di Kabupaten Bangka Selatan belum mencapai overfishing akan tetapi usaha penangkapan pada tahun 2014 sudah melebihi batas optimum. Sedangkan produksi penangkapan ikan pelagis besar pada tahun 2014 sudah melebihi batas MSY dan usaha optimumnya. Oleh sebab itu, perlu dilakukan pengurangan usaha penangkapan untuk menjaga kelestarian sumberdaya ikan. Perkembangan produksi perikanan selama lima tahun terakhir dapat dilihat pada Tabel 2. Bedasarkan tabel, terlihat bahwa produksi perikanan tangkap semakin meningkat.

Tabel 2 Produksi perikanan laut Provinsi Kepulauan Bangka Belitung tahun 2012 - 2017

\begin{tabular}{lcccccc}
\hline \multirow{2}{*}{ Kabupaten/Kota } & \multicolumn{7}{c}{ Produksi Perikanan Laut (ton) } \\
\cline { 2 - 7 } & $\mathbf{2 0 1 2}$ & $\mathbf{2 0 1 3}$ & $\mathbf{2 0 1 4}$ & $\mathbf{2 0 1 5}$ & $\mathbf{2 0 1 6}$ & $\mathbf{2 0 1 7}$ \\
\hline Kab. Bangka & $24.052,00$ & $25.034,70$ & $26.756,90$ & $6.322,30$ & $4.463,60$ & $34.136,74$ \\
Kab. Belitung & $43.304,70$ & $44.947,40$ & $50.134,60$ & $43.738,10$ & $65.169,50$ & $71.760,43$ \\
Kota Pangkal & & & & & & \\
Pinang & $24.328,70$ & $18.144,00$ & $18.066,40$ & $1.832,00$ & $2.088,50$ & $2.941,39$
\end{tabular}


Kab. Bangka

Barat

$12.109,70$

$11.098,80$

$12.642,40$

$14.113,50$

$12.960,10$

$12.756,76$

Kab. Bangka

Tengah

$16.890,00$

$17.559,10$

$16.661,40$

$18.843,90$

$22.988,10$

$24.128,20$

Kab. Bangka

Selatan

$44.185,50$

$44.975,30$

$39.489,60$

$18.269,60$

41.309,60

$37.382,28$

Kab. Belitung

\begin{tabular}{lrrrrrr} 
Timur & $37.694,60$ & $37.482,10$ & $39.533,10$ & $36.423,60$ & $39.593,20$ & $34.853,37$ \\
\hline Provinsi Kep. & $202.565,20$ & $199.241,40$ & $203.284,40$ & $139.542,90$ & $188.572,60$ & $217.959,17$ \\
Bangka Belitung & & & & &
\end{tabular}

Sumber: DKP Provinsi Kepulauan Bangka Belitung, 2018

Perkembangan produksi perikanan laut berdasarkan produksi tahunan, memiliki kisaran yang hampir sama, mulai tahun 2012 sampai dengan tahun 2017, kecuali pada tahun 2015. Pada tahun 2015, produksi perikanan laut menurun secara signifikan atau berbeda trend/polanya jika dibandingkan dengan tahun yang lain. Produksi perikanan pada tahun 2015 semua kabupaten/kota di Provinsi Kepulauan Bangka Belitung mengalami penurunan dimana produksi perikanan laut di Kabupaten Belitung cenderung sama antara tahun 2012 sampai 2014 dan mengalami peningkatan pada tahun 2016 dan 2017. Pendapatan regional berhubungan erat dengan aktivitas produksi yang berlangsung di suatu wilayah. Semakin besar nilai tambah yang dihasilkan dari aktivitas produksi, maka semakin besar pendapatan yang tercipta. Realisasi penerimaan APBD Provinsi Kepulauan Bangka Belitung tahun 2017 mencapai 2.360 miliar rupiah dengan total realisasi belanja 2.468 miliar rupiah. Perekonomian Provinsi Kepulauan Bangka Belitung tahun 2017 ditopang oleh Industri Pengolahan dengan kontribusi dan penyumbang pertumbuhan tertinggi. PDRB per kapita pada tahun 2017 juga ikut meningkat yaitu sebesar 5,31 persen ( $\operatorname{Rp} 48.902 .749,00$ pada tahun 2017). Kegiatan perekonomian perikanan tangkap menghasilkan nilai produksi sekitar 6.730 juta rupiah pada tahun 2017. Nilai produksi ini meningkat jika dibandingkan dengan nilai produksi pada tahun 2016 yaitu sebesar 4.266 juta rupiah. Jenis ikan yang dominan tertangkap adalah tembang, japuh, tenggiri, teri, siro, kurisi, ekor kuning atau pisang-pisang, kakap merah/bambangan, rajungan dan cumi-cumi. Sapanli (2009), menyatakan bahwa kontribusi sektor kelautan dan perikanan di Provinsi 
Kepulauan Bangka Belitung cukup besar dan pembangunan sektor perikanan menjadi prioritas pertama dalam meningkatkan pendapatan daerah.

Tabel 3 Jumlah RTP di Provinsi Kepulauan Bangka Belitung

\begin{tabular}{lrrrrrr}
\hline \multirow{2}{*}{ Kab/Kota } & \multicolumn{7}{c}{ Jumlah RTP } \\
\cline { 2 - 7 } & $\mathbf{2 0 1 2}$ & $\mathbf{2 0 1 3}$ & $\mathbf{2 0 1 4}$ & $\mathbf{2 0 1 5}$ & $\mathbf{2 0 1 6}$ & $\mathbf{2 0 1 7}$ \\
\hline Kabupaten Bangka & 4.998 & 4.998 & 5.047 & 6.981 & 8.902 & 2.981 \\
Kabupaten Belitung & 9.514 & 9.514 & 9.514 & 7.317 & 9.090 & 4.634 \\
Kota Pangkal Pinang & 2.574 & 1.519 & 1.519 & 2.094 & 2.248 & 774 \\
Kabupaten Bangka Barat & 2.151 & 2.896 & 2.896 & 6.262 & 8.267 & 3.619 \\
Kabupaten Bangka Tengah & 6.494 & 6.494 & 4.167 & 5.943 & 6.547 & 3.824 \\
Kabupaten Bangka Selatan & 7.728 & 7.728 & 4.808 & 4.030 & 7.797 & 1.994 \\
Kabupaten Belitung Timur & 6.100 & 6.250 & 6.257 & 3.671 & 3.671 & 2.462 \\
\hline Provinsi Kep. Bangka Belitung & 39.559 & 39.399 & 34.208 & 36.298 & 46.522 & 20.288
\end{tabular}

Sumber: DKP Provinsi Kepulauan Bangka Belitung, 2018

Jumlah rumah tangga yang melakukan kegiatan penangkapan dan pengolahan ikan di wilayah Provinsi Kepulauan Bangka Belitung cukup banyak. Hal ini disebabkan wilayah Provinsi Kepulauan Bangka Belitung memiliki wilayah lautan yang cukup luas yaitu sekitar $65.302 \mathrm{~km}^{2}$ dan panjang garis pantai mencapai $1.200 \mathrm{~km}$. Berdasarkan dengan data yang diperoleh, jumlah RTP perikanan tangkap di Provinsi Kepulauan Bangka Belitung mengalami penurunan yang cukup tinggi yang sebelumnya tahun 2016 sebanyak 46.522 RTP, menjadi 20.288 RTP pada tahun 2017.

Tabel 4 Jumlah armada kapal di Provinsi Kepulauan Bangka Belitung tahun 2012-2017

\begin{tabular}{lrrrrrr}
\hline \multirow{2}{*}{ Kab/Kota } & \multicolumn{5}{c}{ Jumlah Armada Kapal/Perahu (unit) } \\
\cline { 2 - 7 } & $\mathbf{2 0 1 2}$ & $\mathbf{2 0 1 3}$ & $\mathbf{2 0 1 4}$ & $\mathbf{2 0 1 5}$ & $\mathbf{2 0 1 6}$ & $\mathbf{2 0 1 7}$ \\
\hline Kabupaten Bangka & 2.334 & 2.334 & 2.334 & 726 & 2.063 & 2.981 \\
Kabupaten Belitung & 2.586 & 2.586 & 2.586 & 1.219 & 2.488 & 2.472 \\
Kota Pangkal Pinang & 1.139 & 1.139 & 1.123 & 627 & 627 & 2.215 \\
Kabupaten Bangka Barat & 1.624 & 2.024 & 2.257 & 2.369 & 2.582 & 2.221
\end{tabular}




\begin{tabular}{lrrrrrr}
\hline \multirow{2}{*}{ Kab/Kota } & \multicolumn{5}{c}{ Jumlah Armada Kapal/Perahu (unit) } \\
\cline { 2 - 7 } & $\mathbf{2 0 1 2}$ & $\mathbf{2 0 1 3}$ & $\mathbf{2 0 1 4}$ & $\mathbf{2 0 1 5}$ & $\mathbf{2 0 1 6}$ & $\mathbf{2 0 1 7}$ \\
\hline Kabupaten Bangka Tengah & 2.364 & 2.381 & 2.381 & 211 & 1.766 & 3.672 \\
Kabupaten Bangka Selatan & 4.241 & 4.215 & 1.971 & 860 & 1.608 & 2.559 \\
Kabupaten Belitung Timur & 2.450 & 2.453 & 2.453 & 272 & 272 & 749 \\
\hline Provinsi Kep. Bangka Belitung & $\mathbf{1 6 . 7 3 8}$ & $\mathbf{1 7 . 1 3 2}$ & $\mathbf{1 5 . 1 0 5}$ & $\mathbf{6 . 2 8 4}$ & $\mathbf{1 1 . 4 0 6}$ & $\mathbf{1 6 . 8 6 9}$
\end{tabular}

Sumber: DKP Provinsi Kepulauan Bangka Belitung, 2018

Sebagian besar nelayan di Provinsi Kepulauan Bangka Belitung melakukan kegiatan penangkapan dengan menggunakan alat tangkap yang beragam dengan rata-rata kapal yang digunakan memiliki ukuran 5-22 GT. Bentuk dan ukuran kapal/perahu alat tangkap jaring insang, pancing dan bubu yang digunakan umumnya sama. Hal ini disebabkan karena pemilik kapal biasanya mempunyai lebih dari satu alat tangkap yang dioperasikan oleh nelayan. Armada kapal yang digunakan sebagian besar nelayan adalah jenis kapal kayu dengan ukuran bervariasi, umumnya memilki panjang 12-18 $\mathrm{m}$ dengan lebar 2-3 $\mathrm{m}$ dan tinggi $2 \mathrm{~m}$. Mesin penggerak yang digunakan adalah jenis mesin mobil yang berkekuatan antara 100-120 PK. Armada perikanan tangkap di Provinsi Kepulauan Bangka Belitung terbagi dalam 3 kategori yaitu perahu tanpa motor, perahu motor tempel dan kapal motor. Pada tahun 2017, jumlah perahu tanpa motor sebanyak 952 unit, perahu motor tempel sebanyak 4.282 unit dan kapal motor sebanyak 6.892 unit. Jika dilihat pada Tabel 5, penurunan jumlah armada penangkapan sangat signifikan. Hal ini mengakibatkan penurunan jumlah produksi hasil tangkapan yang didaratkan di wilayah perairan Provinsi Kepulauan Bangka Belitung.

Tabel 5 Jumlah alat tangkap di Provinsi Kepulauan Bangka Belitung tahun 2012-2016

\begin{tabular}{lrrrrrrr}
\hline \multirow{2}{*}{ Kab/Kota } & \multicolumn{7}{c}{ Jumlah Alat Penangkapan Ikan (unit) } \\
\cline { 2 - 8 } & $\mathbf{2 0 1 0}$ & $\mathbf{2 0 1 1}$ & $\mathbf{2 0 1 2}$ & $\mathbf{2 0 1 3}$ & $\mathbf{2 0 1 4}$ & $\mathbf{2 0 1 5}$ & $\mathbf{2 0 1 6}$ \\
\hline Kabupaten Bangka & 2.992 & 2.765 & 2.765 & 2.765 & 2.765 & 1.717 & 2.937 \\
Kabupaten Belitung & 36.994 & 5.910 & 6.867 & 5.084 & 4.384 & 1.302 & 1.523 \\
Kota Pangkal Pinang & 11.858 & 8.622 & 8.622 & 6.195 & 6.729 & 627 & 752 \\
Kabupaten Bangka Barat & 12.817 & 6.441 & 6.089 & 8.647 & 9.499 & 3.581 & 3.609 \\
Kabupaten Bangka Tengah & 2.792 & 2.922 & 2.991 & 3.620 & 3.419 & 1.644 & 1.773 \\
Kabupaten Bangka Selatan & 17.129 & 15.784 & 14.076 & 14.073 & 6.286 & 1.123 & 1.997
\end{tabular}




\begin{tabular}{lrrrrrrr} 
Kabupaten Belitung Timur & 19.681 & 20.078 & 20.078 & 19.429 & 15.621 & 771 & 788 \\
\hline Provinsi Kep. Bangka Belitung & 104.263 & 62.522 & 61.488 & 59.813 & 48.703 & 10.765 & 13.379
\end{tabular}

Sumber: DKP Provinsi Kepulauan Bangka Belitung, 2018

Alat penangkapan ikan yang dioperasikan oleh nelayan di perairan Provinsi Kepulauan Bangka Belitung cukup banyak. Alat tangkap yang paling dominan antara lain: purse seine, pukat pantai, payang, pukat udang, bagan perahu, bagan tancap, jaring insang, bubu, sero, pancing ulur, pancing cumi dan alat penangkap kepiting. Alat tangkap jenis jaring lingkar (purse seine) dapat ditemukan di Pelabuhan Perikanan Nusantara (PPN) Sungailiat dan PPN Tanjung Pandan. Sedangkan alat tangkap lainnya hampir dapat ditemukan di pangkalan pendaratan ikan (PPI) dan dermaga pendaratan ikan yang tersebar di pesisir Provinsi Kepulauan Bangka Belitung. Berdasarkan kajian Febrianto (2008), armada penangkapan di Kabupaten Bangka sudah melebihi kuota optimum untuk penangkapan ikan tenggiri yang menjadi komoditas unggulan Provinsi Kepulauan Bangka Belitung. Oleh sebab itu, diperlukan adanya pengurangan usaha penangkapan melalui pengurangan jumlah armada penangkapan ikan. Penambahan alat dan armada penangkapakan dapat dilakukan untuk pemanfaatan fishing ground lepas pantai menuju zona ekonomi eksklusif (ZEE) yaitu perairan Natuna dan Natuna Utara. Akan tetapi, usaha pengalokasian armada ini tentunya harus mendapat perhatian dari pemerintah pusat melalui pengadaan kapal penangkapan ikan ukuran 30 GT sehingga dapat menjangkau daerah penangkapan yang lebih jauh.

Kegiatan penangkapan ikan yang dilakukan oleh nelayan Provinsi Kepulauan Bangka Belitung berada di Wilayah Pengelolaan Perikanan (WPP) Negara Republik Indonesia 711. Berdasarkan Keputusan Menteri Kelautan dan Perikanan Nomor 50/KEPMENKP/ 2017 tentang Estimasi Potensi, Jumlah Tangkapan yang Diperbolehkan, dan Tingkat Pemanfaatan Sumber Daya Ikan di Wilayah Pengelolaan Perikanan Negara Republik Indonesia, diperoleh total potensi ikan yang ada di perairan laut Indonesia sebanyak 12.541.438 Ton, dengan JTB sebanyak 10.033.150 Ton. Sedangkan, potensi perikanan tangkap untuk WPP 711 adalah 767.125 ton/tahun dan JTB sebesar 613.699 ton/tahun. Wilayah ini termasuk Selat Karimata, Laut Natuna dan Laut Natuna Utara. Secara administratif daerah provinsi yang memiliki kewenangan dan tanggung jawab melakukan pengelolaan sumber daya ikan di WPPNRI 711 terdiri dari 7 (tujuh) pemerintah provinsi yang meliputi Provinsi Kepulauan Riau, Provinsi Riau, Provinsi Jambi, 
Provinsi Sumatera Selatan, Provinsi Kepulauan Bangka Belitung, Provinsi Kalimantan Barat, dan Provinsi Kalimantan Tengah. Menurut Indrajaya (2014), pengembangan perikanan tangkap masing-masing provinsi dapat dilakukan dengan analisis alokasi kuota JTB melalui beberapa pendekatan yang berdasarkan dengan prinsip dasar, yaitu:

1. Perikanan yang berkelanjutan (Sustainable fisheries)

2. Pemanfaatan yang berkeadilan (Equitable distribution of benefits), historis, lokasi geografi/kedekatan dengan SDI, skala usaha, lapangan kerja dan tingkat ekonomi, dan

3. Tanggungjawab sosial dan kepatuhan (Social responsibility and compliance).

Tingkat pemanfaatan ikan adalah jumlah atau nilai persentase yang menunjukkan penggunaan sumberdaya ikan yang telah dimanfaatakan. Tingkat pemanfaatan sumberdaya ikan sering disebut dengan istilah JTB atau Total Allowable Catch (TAC). Setiap wilayah pengelolaan perikanan diharapkan memiliki nilai produksi penangkapan sesuai dengan JTB/TAC sehingga belum melampaui batas Maximum Sustainable Yield/ (MSY) atau potensi lestari. Berdasarkan hasil analisis, alokasi Pemerintah Pusat dan Pemerintah Daerah memiliki proporsi sebesar 32\% dan 68\% terhadap JTB yaitu sebesar 613.699 ton (Tabel 6). Berdasarkan data JTB yang dikeluarkan Pemerintah Pusat, maka alokasi JTB untuk daerah sebesar 417.315,32 ton/tahun dan untuk pusat sebesar 196.383,68 ton/tahun. Hal ini berarti bahwa, pemerintah daerah yang berada di kawasan WPP 711 dapat memanfaatkan usaha perikanan perikanan tangkap yang cukup besar. Usaha perikanan tangkap yang menjadi tanggung jawab pemerintah daerah adalah armada yang berukuran dibawah 30 GT.

Tabel 6 Estimasi potensi, JTB dan tingkat pemanfaatan sumberdaya ikan di WPP 711

\begin{tabular}{lrrc}
\hline \multicolumn{1}{c}{ Jenis Ikan } & Potensi (ton) & JTB (ton) & $\begin{array}{c}\text { Tingkat pemanfaatan } \\
(\mathbf{E}) * *\end{array}$ \\
\hline Ikan Pelagis Kecil & 330.284 & 264.227 & 1.41 \\
Ikan Pelagis Besar* & 185.855 & 148.684 & 0.93 \\
Ikan Demersal & 131.070 & 104.856 & 0.61 \\
Ikan Karang & 20.625 & 16.500 & 1.53 \\
Udang Penaeid & 62.342 & 49.873 & 0.53 \\
Lobster & 1.421 & 1.137 & 0.54 \\
\hline
\end{tabular}




\begin{tabular}{lrrr}
\hline \multicolumn{1}{c}{ Jenis Ikan } & Potensi (ton) & \multicolumn{1}{l}{ JTB (ton) } & $\begin{array}{r}\text { Tingkat pemanfaatan } \\
(\mathbf{E}) * *\end{array}$ \\
\hline Kepiting & 2.318 & 1.854 & 1.09 \\
Rajungan & 9.711 & 7.769 & 1.18 \\
Cumi- cumi & 23.499 & 18.799 & 1.84 \\
\hline Jumlah & $\mathbf{7 6 7 . 1 2 5}$ & $\mathbf{6 1 3 . 6 9 9}$ & \\
\hline
\end{tabular}

Keterangan:

* Ikan pelagis besar non Tuna-Cakalang, seperti: kelompok Marlin (Makaira sp),

kelompok Tongkol (Euthynnus spp) dan Tenggiri (Scomberomorus spp)

** Tingkat pemanfaatan (E):

$\mathrm{E}<0.5=$ Moderate, upaya penangkapan dapat ditambah;

$0.5 \leq \mathrm{E}<1 \quad=$ Fully-exploited, upaya penangkapan dipertahankan;

$\mathrm{E} \geq 1=$ Over-exploited, upaya penangkapan harus dikurangi.

Hasil analisis alokasi kuota JTB untuk pemerintah daerah menunjukan bahwa alokasi kuota JTB perikanan tangkap untuk Provinsi Kepulauan Bangka Belitung yang berada di WPP 711 sebesar $175.916,71$ ton per tahun. Jumlah alokasi kuota ini merupakan alokasi yang sudah terkoreksi dengan pengurangan JTB sebanyak 2,5\%. Pengurangan ini bertujuan untuk memberikan alokasi stok cadangan (stock reservation) bagi daerah atau pengusaha baru yang akan melakukan usaha penangkapan ikan dimasa mendatang. Besaran ini diharapkan dapat ditingkatkan menjadi 10\% selama 5 tahun kedepan untuk tetap menjaga kelestarian sumberdaya ikan dan lingkungannya. Rata-rata produksi perikanan tangkap laut di Provinsi Kepulauan Bangka Belitung selama lima tahun terakhir sekitar 18.7421,42 ton, maka pemanfaatan potensi sudah melebihi batas JTB dengan persentase mencapai 106,54\%. Hasil analisis juga memperlihatkan bahwa telah terjadi over fishing sekitar $112 \%$ jika dibandingkan dengan produksi perikanan tangkap di 7 provinsi dalam WPP 711 pada tahun 2017 yaitu sebanyak 687.720 Ton (KKP, 2018).

Tabel 7 Alokasi JTB kabupaten/kota Provinsi Kepulauan Bangka Belitung 


\begin{tabular}{lrrr}
\hline Kabupaten/Kota & $\begin{array}{r}\text { Statistik } \\
\text { Tangkapan } \\
\text { Rata-rata (ton) }\end{array}$ & $\begin{array}{r}\text { Alokasi Kuota } \\
\text { (Belum Terkoreksi) }\end{array}$ & $\begin{array}{r}\text { Alokasi Kuota } \\
\text { (Terkoreksi) }\end{array}$ \\
\hline Kabupaten Bangka & $21.200,310$ & $12.614,184$ & $14.073,335$ \\
Kabupaten Belitung & $45.074,196$ & $32.115,365$ & $35.830,323$ \\
Kota Pangkal Pinang & $17.332,796$ & $8.493,070$ & $9.475,509$ \\
Kabupaten Bangka & $11.789,616$ & $7.294,825$ & $8.138,657$ \\
Barat & $17.133,200$ & $11.243,663$ & $12.544,278$ \\
Kabupaten Bangka & & & \\
Tengah & $36.863,162$ & $22.809,081$ & $25.447,531$ \\
Kabupaten Bangka & & & \\
Selatan & $38.028,160$ & $26.382,036$ & $29.433,789$ \\
Kabupaten Belitung & & & \\
Timur & $187.421,420$ & $134.943,422$ & $175.916,715$ \\
\hline $\begin{array}{l}\text { Provinsi Kep.Bangka } \\
\text { Belitung }\end{array}$ & & & \\
\hline
\end{tabular}

Tingkat pemanfaatan sumberdaya ikan di perairan Provinsi Kepulauan Bangka Belitung termasuk kategori over-exploited sehingga perlu adanya program pengendalian dengan pengurangan upaya penangkapan antara lain pengurangan jumlah alat tangkap atau armada penangkapan serta adanya moratorium daerah penangkapan (closed area). Prinsip dasar yang mendasari ide pengelolaan adalah bahwa pemanfaatan sumberdaya harus didasarkan pada sistem dan kapasitas daya dukung (carrying capacity) alamiahnya (Charles 2001; Saputra, 2009). Besar kecilnya hasil tangkapan tergantung pada jumlah stok alami yang tersedia di perairan dan kemampuan alamiah dari habitat untuk menghasilkan biomassa. Berdasarkan data KKP (2018) bahwa produksi perikanan tangkap nasional pada tahun 2017 sekitar 6.424 .113 ton, jika dibandingkan dengan potensi yang ada, maka peluang pengembangan masih sangat besar dimana potensi pemanfaatan berdasarkan JTB saat ini yaitu sekitar 64\%. Besaran alokasi kuota sumberdaya ikan untuk perairan Provinsi Kepulauan Bangka Belitung diharapkan dapat dilaksanakan sehingga terwujud sistem penangkapan ikan yang berkelanjutan. 


\section{KESIMPULAN DAN SARAN}

Kondisi perikanan tangkap di peraran laut pesisir Provinsi Kepulauan Bangka Belitung sudah mengalami kelebihan penangkapan (overfishing) yaitu melampaui JTB sekitar 106,54\%. Alokasi kuota penangkapan untuk wilayah perairan Provinsi Kepulauan Bangka Belitung setiap tahun diharapkan berada pada kisaran $175.916,71$ ton sehingga tercipta usaha penangkapan ikan yang berkelanjutan. Rata-rata produksi perikanan tangkap di Provinsi Kepulauan Bangka Belitung mulai tahun 2012-2017 sekitar 18.7421,42 ton yang sebagian besar didaratkan di PPN Sungailiat dan PPN Tanjung Pandan. Alokasi JTB untuk daerah WPP 711 sebesar 417.315,32 ton/tahun sedangkan untuk Pemerintah Pusat mendapat alokasi sekitar 196.383,68 ton/tahun. Alokasi untuk Pemerintah Pusat ini adalah khusus untuk kapal penangkapan ikan yang berukuran minimal 30 GT.

Arah kebijakan pengembangan usaha perikanan tangkap di kawasan pesisir Provinsi Kepulauan Bangka Belitung antara lain pengendalian kegiatan usaha penangkapan di daerah pesisir (dibawah 12 mil) dan mengarahkan daerah penangkapan ikan menuju laut lepas (zona ekonomi ekslusif), yaitu sekitar laut Natuna. Oleh sebab itu, diperlukan peran pemerintah pusat untuk pengembangan program peningkatan skala usaha penangkapan menengah dan besar dengan armada penangkapan diatas 30 GT. Pengembangan yang berorientasi pada pembangunan perikanan yang bertanggungjawab (sustainable and responsibility development fisheries) dan menyeimbangkan pertumbuhan ekonomi (economic growth) baik lokal maupun regional. Selain itu, perlu dikaji juga jumlah alat tangkapan dan armada penangkapan yang optimum di Provinsi Kepulauan Bangka Belitung yang sesuai dengan alokasi kuota sumberdaya ikan yang ditetapkan oleh pemerintah pusat.

\section{DAFTAR PUSTAKA}

[BPS] Badan Pusat Statistik. 2018. Provinsi Kepulauan Bangka Belitung Dalam Angka. Berita Resmi Statistik Perikanan 209-216.

Dinas Kelautan dan Perikanan Provinsi Kepulauan Bangka Belitung. 2017. Statitik Perikanan Provinsi Kepulauan Bangka Belitung. Kota Pangkal Pinang.

Febrianto, Arief. 2008. Pengembangan Usaha Perikanan Tenggiri di Kabupaten Bangka Provinsi Kepulauan Bangka Belitung: Suatu Pendekatan Sistem Bisnis Perikanan. Tesis. Sekolah Pascasarjana. Institut Pertanian Bogor. Bogor

[KKP] Kementerian Kelautan dan Perikanan. 2015. Statistik Perikanan Tangkap Di Laut Menurut Wilayah Pengelolaan Perikanan Negara Republik Indonesia (WPP-NRI) 20052014. Jakarta. 
Mayu, D.H., Kurniawan, A.Febrianto. 2018. Analisis Potensi dan Tingkat Pemanfaatan Sumberdaya Ikan di Perairan Kabupaten Bangka Selatan. Jurnal Perikanan Tangkap. 2:3041

Sapanli, Kastana. 2009. Analisis Kebijakan Pembangunan Ekonomi Kelautan di Provinsi Kepulauan Bangka Belitung. Tesis. Sekolah Pascasarjana. Institut Pertanian Bogor. Bogor

Saputra, Suradi Wijaya. 2009. Dinamika Populasi Ikan Berbasis Riset. Badan Penerbit Universitas Diponegoro. Semarang.

Jaya, I. 2014. Penentuan Alokasi Sumberdaya Ikan Pusat dan Daerah. Fakultas Perikanan dan Ilmu Kelautan IPB. Bogor.

Dahuri, Rokhmin, J Rais, SP Ginting dan MJ Sitepu. 1996. Pengelolaan Sumberdaya Wilayah Pesisir dan Lautan Secara Terpadu. Penerbit Pratnya Paramita. Jakarta. 305 hal. 